\title{
PERSEPSI PERAWAT TENTANG DAMPAK AKREDITASI DI RUMAH SAKIT BUDI MULIA BITUNG
}

\section{[NURSES PERCEPTIONS ABOUT THE IMPACT OF ACCREDITATION MIND AND NOBLE IN HOSPITAL BITUNG]}

\author{
Brigitte David ${ }^{1}$, Monica Suparlan ${ }^{2}$, Brigita Maria Tambengi ${ }^{3}$, Marta Kanis Ohoiledwarin ${ }^{4}$ \\ Akper Gunung Maria Tomohon 1,4 , RS Budi Mulia Bitung ${ }^{2,3}$ \\ e-mail : sungita005@gmail.com \\ DOI : 10.47718/jpd.v8i01.1154
}

\section{ABSTRAK}

Latar Belakang: Akreditasi menunjukkan komitmen nyata sebuah Rumah Sakit dalam memperbaiki mutu pelayanan dan meningkatkan keselamatan pasien di Rumah Sakit. Karena itu, perlu ada kesamaan persepsi tentang manfaat akreditasi Rumah Sakit, agar semua karyawan berperan aktif dalam proses pengmbangan RS sesuai standar pemerintah. Tujuan: penelitian ini untuk mengetahui persepsi perawat tentang dampak akreditasi di Rumah Sakit Budi Mulia Bitung. Metode: penelitian ini menggunakan metode kualitatif pendekatan fenomenologi, dengan teknik pengambilan sampel yang digunakan Nonprobability Sampling dilakukan dengan teknik Purposive Sampling. Partisipan berjumlah 6 orang perawat pelaksana yang bekerja minimal 3 tahun dan telah mengikuti proses akreditasi Rumah Sakit. Pengumpulan data dilakukan dengan wawancara mendalam dalam bentuk Focused Group Discussion (FGD) / Diskusi Kelompok Fokus menggunakan pedoman wawancara. Data akan dianalisa dengan metode analisis konten. Uji keabsahan data yang dilakukan meliputi Uji Credibility, Uji Dependability, dan Uji Confirmability. Hasil: penelitian ini merujuk pada 3 tema yang menunjukkan bahwa (1) Pemahaman perawat mengenai pengertian akreditasi Rumah Sakit masih kurang, pemahaman partisipan lebih pada tujuan akreditasi. (2) Pengaruh pelaksanaan akreditasi Rumah Sakit terhadap pelayanan keperawatan dapat memberikan dampak yang positif dan negatif. (3) Strategi perawat dalam menghadapi akreditasi Rumah Sakit sudah sesuai dengan pendapat para ahli. Simpulan: persepsi perawat berpengaruh pada partisipasi untuk memenuhi tujuan akreditasi 
Rumah Sakit, yang memiliki dampak positif dan negatif, maka perlu adanya upaya dan strategi dari manajemen Rumah Sakit Budi Mulia Bitung. Berdasarkan hasil penelitian ini disarankan bagi perawat untuk mengikuti pelatihan dan sosialisasi yang diberikan oleh Tim Akreditasi Rumah Sakit. Selanjutnya perawat dapat berpikir rasional, kreatif dan inovatif mengenai hambatan yang dirasakan dalam pemberian pelayanan perawatan setelah akreditasi.

Kata Kunci: Persepsi Perawat, Dampak, Akreditasi Rumah Sakit.

\section{ABSTRACT}

Introduction: Accreditation shows a hospital's real commitment in improving the quality of services and improving patient safety in hospitals. Therefore, there needs to be a common perception about the benefits of hospital accreditation, so that all employees play an active role in the process of developing hospitals according to government standards. Aim: this study to find out the perception of nurses about the impact of accreditation at Budi Mulia Bitung Hospital. Method: This research uses qualitative method of phenomenological approach, with sampling technique used nonprobability sampling done by Purposive Sampling technique. Participants numbered 6 implementing nurses who worked for at least 3 years and had followed the hospital accreditation process. Data collection is conducted by in-depth interviews in the form of Focused Group Discussion (FGD) / Focus Group Discussion using interview guidelines. The data will be analyzed by content analysis method. Data validity tests include Credibility Test, Dependability Test, and Confirmability Test. Result: this study refers to 3 themes that show that (1) Nurses' understanding of the understanding of hospital accreditation is still lacking, participants' understanding is more on accreditation objectives. (2) The effect of the implementation of hospital accreditation on nursing services may have a positive and negative impact. (3) The nurse's strategy in dealing with hospital accreditation is in accordance with the opinion of experts. Conclusion: the perception of nurses has an effect on participation to meet the hospital accreditation objectives, which have a positive and negative impact, so there needs to be efforts and strategies from the management of Budi Mulia Bitung Hospital. Based on the results of 
this research, it is recommended for nurses to participate in training and socialization provided by the Hospital Accreditation Team. Furthermore, nurses can think rationally, creatively and innovatively about the perceived obstacles in providing care services after accreditation.

Keywords: Nurse Perception, Impact, Hospital Accreditation.

\section{PENDAHULUAN}

Sejalan dengan berkembangnya zaman, persoalan mutu dan peningkatan mutu pelayanan kesehatanpun menjadi persoalan penting bagi Rumah Sakit untuk memberikan pelayanan yang optimal sesuai standar kepada pasien. Berbagai upaya peningkatan mutu telah dikembangkan oleh Kementerian Kesehatan diantaranya adalah akreditasi lembaga pemberi pelayanan kesehatan. Karena itu momentum akreditasi merupakan strategi utama peningkatan mutu pelayanan Rumah Sakit. Akreditasi Rumah Sakit di Indonesia dilaksanakan untuk menilai kepatuhan standar akreditasi. Kendati demikian, kesadaran akan pentingnya akreditasi bagi peningkatan mutu pelayanan pasien walaupun mengalami peningkatan dalam prevalensi tapi masih belum dimaknai secara tepat.

Dampak akreditasi bagi Rumah Sakit adalah Rumah Sakit dapat mengetahui sejauh mana pelayanan di Rumah Sakit tersebut memenuhi standar yang berlaku secara Nasional. Status terakreditasi juga dapat meningkatkan kepercayaan masyarakat atas layanan di Rumah Sakit dan sebagai alat pencegahan terjadinya kasus malpraktik, karena dalam melaksanakan tugasnya, tenaga di Rumah Sakit telah memilki Standar Prosedur Operasional (SPO) yang jelas. Akreditasi 
Rumah Sakit mempunyai dampak positif terhadap kualitas perawatan yang diberikan kepada pasien dan kepuasan pasien (Yildiz, 2014). Penerapan standar akreditasi mendorong perubahan pelayanan Rumah Sakit yang lebih berkualitas dan peningkatan kerjasama antara disiplin profesi dalam perawatan pasien (Manzo, 2012). Akreditasi akan menjadi indikator penjamin mutu dan pelayanan Rumah Sakit pada pasien, dibuktikan dengan kelengkapan dan kecakapan seluruh tenaga atau Sumber Daya Manusia (SDM) di Rumah Sakit. Tenaga perawat memberikan kontribusi besar terhadap keberhasilan pelayanan kesehatan paripurna kepada klien (Potter dan Perry, 2013).

Persepsi mengenai manfaat dilaksanakannya akreditasi Rumah Sakit akan membuat standar akreditasi menjadi pedoman bagi seluruh karyawan terhadap pekerjaan rutinnya. Karena itu, perlu ada kesamaan persepsi tentang manfaat akreditasi Rumah Sakit, agar semua karyawan berperan aktif, dengan dorongan monitoring para pimpinan. Menurut Robbins \& Judge (2013) menyatakan bahwa persepsi dapat berpengaruh langsung terhadap partisipasi. Partisipasi dapat meningkatkan komitmen terhadap keputusan. Persepsi mempunyai peran positif terhadap kinerja karyawan atau produktivitas kerja. Penelitian Mandawati, M. (2018) menunjukkan bahwa perawat memiliki persepsi positif terhadap pelaksanaan akreditasi di RSUD Setjonegoro Wonosobo. Dampak positif dari pelaksanaan akreditasi bagi pelayanan keperawatan adalah meningkatnya usaha keselamatan pasien yang dilakukan oleh perawat. Selain dampak positif akreditasi ada juga dampak negatifnya, yaitu: 
menyita waktu dan tenaga serta dokumentasi menjadi lebih banyak.

Perawat memberikan kontribusi besar terhadap keberhasilan pelayanan kesehatan paripurna kepada klien (Potter dan Perry, 2013). Oleh karena itu, pembentukan persepsi positif terhadap dampak akreditasi ini perlu dikembangkan dalam diri perawat demi memaksimalkan mutu pelayanan terhadap pasien sebagaimana yang menjadi tujuan utama penyelenggaraan akreditasi Rumah Sakit itu sendiri. Jika tidak demikian maka seluruh bentuk pelayanan perawat akan menjadi suatu rutinitas tanpa makna karena telah terpolarisasi dalam sikap formalitas prosedural. Disinilah perawat akan salah mempersepsikan pelaksanaan akreditasi sebagai suatu beban tambahan dalam karya pelayanannya.

Untuk menunjang kegiatan akreditasi Rumah Sakit tersebut, telah dikembangkan berbagai standar akreditasi Rumah Sakit. Standar akreditasi Rumah Sakit yang saat ini digunakan oleh pemerintah adalah Standar Nasional Akreditasi Rumah Sakit Edisi 1 (SNARS Edisi 1). Dalam Akreditasi versi SNARS Edisi 1, Rumah Sakit lebih mendengarkan keluhan / kritik dan saran dari pasien dan keluarganya. Disamping itu Rumah Sakit juga wajib menghormati hak-hak pasien dan melibatkan pasien dalam proses perawatan sebagai mitra. Pasien dan keluarga di ajak berdialog dalam menentukan perawatan yang terbaik. Dampak yang diharapkan bahwa Rumah Sakit yang melakukan upaya peningkatan mutu pelayanan dan keselamatan pasien, dapat meningkatkan kepercayaan masyarakat (Rahma, 2012).

Berdasarkan data KARS (Komisi Akreditasi Rumah Sakit) pada 
tahun 2015 tercatat baru 284 Rumah Sakit yang terakreditasi secara Nasional dari 2.415 Rumah Sakit yang terdaftar di Indonesia. Jumlah Rumah Sakit yang belum terakreditasi yaitu 2.131 sehingga secara proporsi baru 11,75\% Rumah Sakit terakreditasi di Indonesia. Pada tahun 2019 data KARS (Komisi Akreditasi Rumah Sakit) saat ini terdapat sekitar 856 Rumah Sakit yang belum terakreditasi, 64 Rumah Sakit memiliki akreditasi yang kadaluwarsa, sejumlah 1.969 Rumah Sakit telah terakreditasi, serta hanya 1 Rumah Sakit yang terakreditasi KARS Internasional.

Rumah Sakit Budi Mulia Bitung adalah satu-satunya Rumah Sakit swasta di Kota Bitung dan telah melewati beberapa kali survei oleh Komisi Akreditasi Rumah Sakit (KARS) yaitu pada bulan juni tahun 2019 ini, Rumah Sakit telah di survey penilaian akreditasi versi SNARS Edisi 1 dan lulus dengan Tingkat Madya (3 Bintang), artinya dalam kurun waktu tiga tahun Rumah Sakit Budi Mulia Bitung menuju Paripurna (5 Bintang).

Menurut peneliti, persepsi tentang dampak atau manfaat akreditasi Rumah Sakit sangat penting bagi seluruh karyawan yang bekerja di Rumah Sakit. Sebagaimana yang telah diuraikan sebelumnya bahwa persepsi mempunyai peran positif terhadap kinerja karyawan atau produktivitas kerja. Oleh karena itu, sangat diperlukan adanya kesamaan persepsi semua karyawan terhadap manfaat atau dampak akreditasi Rumah Sakit. Dengan adanya kesamaan persepsi ini, akan tercipta sinergitas pelayanan dari semua unsur Rumah Sakit. Dengan kata lain, standar akreditasi akan menjadi pedoman bagi seluruh 
karyawan terhadap pekerjaan rutinnya. Dalam konteks inilah, peneliti merasa tertarik untuk meneliti persepsi perawat tentang dampak akreditasi Rumah Sakit. Hal ini sangat penting karena: Pertama, perawat sebagai tenaga profesional merupakan tenaga mayoritas yang berada di lingkungan Rumah Sakit. Berhasil atau tidaknya tindakan pelayanan kesehatan paripurna kepada klien sangat ditentukan oleh kinerja perawat. Kedua, di sisi lain, banyak perawat masih memiliki persepsi negatif terhadap dampak akreditasi Rumah Sakit. Berdasarkan hasil pengamatan peneliti, sebagian besar perawat merasa bahwa penyelenggaraan akreditasi hanya menambah beban pekerjaan saja. Penyelenggaraan akreditasi hanya di pandang sebagai tuntutan pekerjaan harian.

Berdasarkan fenomena diatas, maka peneliti tertarik untuk meneliti Persepsi Perawat Tentang Dampak Akreditasi Rumah Sakit.

\section{METODE PENELITIAN}

Desain penelitian ini bersifat kualittatif fenomenologi Penelitian ini dilakukan di RS Budi Mulia Bitung Januari sampai dengan April 2020. dilakukan dengan teknik Purposive Sampling. Partisipan berjumlah 6 orang perawat pelaksana yang bekerja minimal 3 tahun dan telah mengikuti proses akreditasi Rumah Sakit. Pengumpulan data dilakukan dengan wawancara mendalam dalam bentuk Forum Diskusi Group (FDG) menggunakan pedoman wawancara. Data akan dianalisa dengan metode analisis konten. Uji keabsahan data yang dilakukan meliputi Uji Credibility, Uji Dependability, dan Uji Confirmability. 
Pada tanggal 23 Desember 2019 peneliti melakukan kunjungan ke Rumah Sakit Budi Mulia Bitung untuk mohon izin penelitian. Peneliti melakukan wawancara secara mendalam dalam bentuk diskusi group kepada 6 partisipan dengan menggunakan pedoman wawancara, yang dimulai dengan memperkenalkan diri, menjelaskan maksud dan tujuan prosedur penelitian yang akan dilakukan, dilanjutkan dengan penandatanganan bersedia menjadi partisipan (informed consent). Saat pengambilan data wawancara dimulai, alat recording dijalankan dan peneliti menanyakan pertanyaan demi pertanyaan kepada seluruh partisipan, mendengarkan secara teliti dan mencatat hal hal yang diungkapkan partisipan untuk mengetahui pemahaman partisipan. Hasil wawancara direkam dan di transkrip datanya pada saat itu. Dalam proses penelitian terdapat partisipan yang berhalangan hadir. Pada tanggal 18 januari 2020 peneliti kembali melakukan kontrak waktu menemui dua partisipan yang dari hasil wawancara datanya belum jenuh dengan wawancara mendalam. Dan pada tanggal 20 Januari 2020 peneliti melakukan membercheck ke Kepala Ruangan masing-masing partisipan.

\section{HASIL DAN}

PEMBAHASAN

\section{Karakteristik Partisipan}

Pada penelitian ini, partisipan berjumlah 6 orang. Partisipan adalah perawat yang bekerja minimal 3 tahun dan mengikuti proses akreditasi di Rumah Sakit Budi Mulia Bitung. 


\begin{tabular}{cccccc}
\hline Partisipan & Umur (Thn) & Lama Kerja (Thn) & Pendidikan & Ruangan & Jabatan \\
\hline P1 & 24 & 5 & D III & VIP & PP \\
\hline P2 & 29 & 8 & S1 Kep & IBS & PP \\
\hline P3 & 28 & 5 & S1 Ners & St.Theresia & PP \\
\hline P4 & 33 & 12 & S1 Ners & IBS & PP \\
\hline P5 & 32 & 10 & D III & IGD & PP \\
\hline P6 & 43 & 22 & D III & St.Lusia & PP \\
\hline
\end{tabular}

\section{Penentuan Tema}

Hasil pengolahan data ditemukan 3 tema mengenai persepsi perawat tentang dampak akreditasi Rumah Sakit.

Tema I: Pemahaman perawat tentang akreditasi Rumah Sakit

Tema ini teridentifikasi melalui dua kategori yang di peroleh dari hasil wawancara kepada partisipan untuk mengetahui pemahaman perawat tentang akreditasi Rumah Sakit yang dialami langsung oleh partisipan. Kategori tersebut adalah (1) Pengetahuan perawat tentang akreditasi; (2) Penilaian perawat tentang manfaat akreditasi.

Tema II: Strategi perawat dalam menghadapi akreditasi Rumah Sakit

Tema ini teridentifikasi melalui 3 kategori yaitu: (1) Persiapan Rumah Sakit menghadapi akreditasi; (2) Kiat perawat memenuhi harapan akreditasi; (3) Hambatan perawat setelah akreditasi.

Tema III: Pengaruh akreditasi terhadap pelayanan perawatan

Tema ini teridentifikasi melalui dua kategori yaitu: (1) Pendapat perawat tentang akreditasi terkait pelayanan keperawatan; (2) Pendapat perawat setelah akreditasi. 


\section{Pembahasan Tema}

Hasil wawancara yang dilakukan terhadap 6 partisipan menghasilkan 3 tema yaitu.

Tema I: Pemahaman perawat tentang akreditasi Rumah Sakit

Peneliti menemukan 1 di antara 6 perawat yang jawabannya sesuai dengan pengertian akreditasi yaitu pengakuan Pemerintah untuk Rumah Sakit. Hal ini selaras dengan pengertian Akreditasi menurut Ensiklopedia Nasional yaitu suatu bentuk pengakuan yang diberikan Pemerintah untuk Lembaga atau Intitusi (Poerwarni Sopacua dan Evi, 2006). Sedangkan untuk tujuan akreditasi adalah peningkatan mutu pelayanan Rumah Sakit baik dari segi fasilitas, manajemen dan terlebih lagi kepercayaan masyarakat kepada Rumah Sakit yang sudah memenuhi standar keselamatan pasien. Hal ini sesuai dengan yang tercantum dalam Permenkes RI Nomor 34 Tahun 2017 bahwa tujuan akreditasi antara lain: meningkatkan mutu pelayanan Rumah Sakit dan melindungi keselamatan pasien, meningkatkan perlindungan bagi masyarakat, Sumber Daya Manusia (SDM) di Rumah Sakit dan sebagai Institusi.

Berdasarkan hasil temuan penelitian dan teori diatas, maka pemahaman partisipan tentang pengertian akreditasi masih terbatas, hal ini disebabkan kurangnya informasi tentang akreditasi, tidak mengikuti pelatihan. Pemahaman partisipan lebih pada tujuan akreditasi, karena partisipan dalam penelitian ini berlatar belakang sebagai perawat pelaksana diruangan bukan sebagai Tim Akreditasi. Seperti yang diketahui bahwa Tim Akreditasi ini mempelajari dan 
menguasai tentang konsep dan instrumen yang terdapat dalam

Standar Nasional Akreditasi Rumah Sakit, sedangkan perawat pelaksana lebih berperan pada lapangan yaitu di masing-masing ruang rawat Rumah Sakit, sehingga perawat pelaksana lebih merasakan secara langsung adalah dampaknya. Hal ini seperti yang diungkapkan oleh Reisi, N., dkk (2018) dalam penelitiannya bahwa pendidikan dan pelatihan; penghargaan dan pengakuan; dan keterlibatan staf adalah faktor yang mempengaruhi hasil kualitas. Akreditasi rumah sakit berdampak positif pada kualitas layanan.

Tema II: Strategi perawat dalam menghadapi akreditasi Rumah Sakit

Berdasarkan hasil penelitian terhadap partisipan untuk mengetahui persiapan akreditasi yaitu: persiapan tim akreditasi, sumber daya manusia (SDM) dalam hal ini tenaga perawat, fasilitas kesehatan, sarana prasarana sesuai standar yang diminta akreditasi. Hal ini sesuai teori Alisa dan Koye (2005) bahwa perencanaan strategi adalah proses sistematis dimana organisasi sepakat membangun komitmen di antara pemangku kepentingan untuk mewujudkan misimisi organisasi dan bertanggung jawab terhadap lingkungan organisasi. Selanjutnya menurut Ayuningtyas (2015) Perencanaan suatu fungsi manajemen yang terpenting karena berbagai fungsi manajemen lainnya baru dapat berperan apabila perencanaan selesai dilakukan dan harus berpedoman pada perencanaan yang telah ditetapkan. Selain itu KARS (2018) menetapkan 5 standar yang digunakan mengacu pada standar yang tercantum dalam standar akreditasi yaitu: 
1) Standar keselamatan pasien

2) Standar yang berfokus pasien

3) Standar manajemen rumah sakit

4) Program nasional

5) Strategi pendidikan kesehatan dalam pelayanan Rumah Sakit

Hasil yang ditemukan berhubungan dengan kiat perawat dalam memenuhi harapan akreditasi adalah kerjasama, komunikasi yang baik antara perawat, dokter dan tenaga lain dalam Rumah Sakit, dan rajin melakukan tindakan sesuai Standar Prosedur Operasional (SPO). Hal ini sesuai teori menurut Salusu (2004) dalam strategi yang baik terdapat koordinasi tim kerja, memiliki tema, mengidentifikasi faktor pendukung sesuai dengan prinsip-prinsip pelaksanaan gagasan, secara rasional efisien dalam memilih teknik untuk mencapai tujuan secara efektif. Terkait pernyataan hambatan yang dirasakan oleh perawat setelah akreditasi, berikut hasil yang ditemukan: tuntutan tanggung jawab bertambah, sebagian perawat kurang kesadaran diri dalam pelaksanaan tugas diruangan, persediaan pasokan persediaan untuk kebutuhan ruangan belum efektif. Sedangkan pernyataan tanggung jawab perawat bertambah, hal ini sesuai dengan pendapat Wang, Hailey, dan Yu (2011) bahwa bidang keperawatan Rumah Sakit memegang peranan yang sangat strategis karena tenaga kesehatan yang paling banyak adalah perawat. Selanjutnya pernyataan sebagian perawat kurang kesadaran diri dalam pelaksanaan tugas di ruangan, hal ini sesuai dengan teori menurut Sudarma (2018) bahwa seorang perawat dalam melakukan setiap perannya bagi individu, keluarga dan 
masyarakat sangat dipengaruhi oleh persepsi perawat itu sendiri tentang perannya. Ini juga selaras dengan penelitian oleh Irwandy (2017) tentang faktor yang berhubungan dengan beban kerja di Rumah Sakit Jiwa Dadi Makassar diperoleh faktor kelelahan dan keletihan yang dirasakan perawat disebabkan karena beban kerja yang tinggi.

Berdasarkan analisis hasil temuan dan teori-teori sebelumnya bahwa akreditasi dapat terlaksana perlu proses interaksi yang baik antara manajemen Rumah Sakit dan perawat, dalam mempersiapkan strategi yang mengacu pada Standar Nasional Akreditasi Rumah Sakit. Sehingga hambatan-hambatan yang dirasakan oleh perawat diruang perawatan tentang menambah tanggung jawab perawat karena peningkatan kunjungan pasien di Rumah Sakit, dapat dikendalikan dan diminimalkan oleh manajemen Rumah Sakit sehingga tercipta lingkungan kerja yang nyaman dan menyenangkan bagi perawat.

Tema III: Pengaruh akreditasi terhadap pelayanan perawatan

Di Tema ini ditemukan bahwa pelayanan perawat dituntut profesional yaitu dengan adanya kegiatan Kredensial dan Rekredensial bagi perawat bertujuan untuk meningkatkan mutu asuhan keperawatan pada pasien sesuai Standar Prosedur Operasional (SPO). Hal ini seperti yang diungkapkan oleh Yildiz (2014) dalam penelitiannya bahwa akreditasi Rumah Sakit mempunyai dampak positif terhadap kualitas perawatan yang diberikan kepada pasien dan kepuasan pasien. misalnya pelaksanaan akreditasi Rumah Sakit mengalami perubahan dari segi pelayanan kepada pasien, alat-alat di 
Rumah Sakit lebih ditingkatkan atau lebih lengkap, sarana dan prasarana yang baik, maka hal ini memberikan rasa nyaman terhadap fasilitas yang tersedia, dan assesment (penilaian) terhadap individu Sumber Daya Manusia (SDM), yaitu lebih ditingkatkan dalam hal mutu pelayanan. Dukungan sarana dan prasarana yang memadai dalam menjamin kualias pelayanan (Adzieman, Mohamad, Ashikin, dan Rahman, 2014). Hasil penelitian ini konsisten dengan penelitian yang dilakukan Mandawati, M (2018), bahwa persepsi positif perawat terhadap akreditasi memberikan dampak yang positif pada perbaikan fasilitas dan lingkungan Rumah Sakit. Dampak yang diharapkan bahwa Rumah Sakit yang melakukan upaya peningkatan mutu pelayanan dan keselamatan pasien dapat meningkatkan kepercayaan masyarakat (Rahma, 2012). Masyarakatpun dapat memilih Rumah Sakit yang baik pelayanannya serta mendapat rasa aman karena pelayanan Rumah Sakit yang dikunjungi telah memenuhi standar, ini sesuai data BOR Rumah Sakit Budi Mulia Bitung yang di dapat 3 bulan sebelum penilaian akreditasi adalah 54,7\% sedangkan setelah akreditasi data BOR mengalami peningkatan menjadi $59,8 \%$.

Sedangkan persepsi negatif yang diungkapkan partisipan adalah persiapan waktu pengisian kelengkapan dokumen menghabiskan waktu kerja. Menurut Nursalam (2011) bahwa dokumentasi keperawatan mempunyai makna yang penting dilihat dari berbagai aspek seperti aspek hukum, kualitas pelayanan, komunikasi, keuangan, pendidikan, penelitian, dan akreditasi. Selain itu partisipan lain mengungkapkan bahwa perawat terlihat lebih siap saat survei 
akreditasi saja tetapi setelah itu akan kembali semula sebagai rutinitas. Hal kesiapan untuk diakreditasi oleh KARS ternyata memiliki daya ungkit lebih dalam upaya peningkatan mutu pelayanan Rumah Sakit. Tetapi hal ini identik dengan hal kepatuhan perawat dalam implementasi adalah suatu hal yang sangat penting. Meskipun sifatnya tidak bisa selalu konsisten. Ada kecenderungan di awal implementasi terjadi peningkatan kepatuhan terhadap standar yang disusun. Namun seiring berjalannya waktu ada beberapa prosedur yang mulai kurang dipatuhi. Prosedur yang sudah menjadi bagian dari pekerjaan seharihari relatif tinggi kepatuhannya. Sedangkan prosedur yang merupakan tugas tambahan setelah adanya akreditasi relatif kurang dipatuhi. Berkaitan dengan itu maka komitmen sangat dibutuhkan dalam hal ini seperti yang diungkapkan dalam penelitian Wijayanti (2008) bahwa semua karyawan atau petugas harus memiliki komitmen yang kuat dalam berusaha memberikan pelayanan kesehatan yang baik.

Berdasarkan hasil penelitian dan penjelasan teori diatas, peneliti dapat menarik kesimpulan bahwa pengaruh akreditasi Rumah Sakit terhadap pelayanan perawatan ada dampak baik, yaitu dengan fasilitas lebih lengkap, pencatatan dokumentasi lebih baik, administrasi lebih tertata rapi. Dan dampak buruknya dapat menambah jam kerja bagi perawat.

\section{Keterbatasan Penelitian}

Dalam pengujian keabsahan data, peneliti tidak melakukan salah satu uji yaitu uji Transferability dikarenakan ketidaktersediaan waktu dari 


\section{KESIMPULAN}

tenaga perawat yang mempunyai karakteristik yang sama dengan

partisipan diskusi group sebelumnya.

Kesimpulan yang didapat dari penelitian ini adalah:

1. Pemahaman perawat mengenai pengertian akreditasi Rumah Sakit masih terbatas.

2. Pengaruh pelaksanaan akreditasi Rumah Sakit terhadap pelayanan keperawatan, dapat memberikan dampak yang positif yaitu fasilitas lebih lengkap, pencatatan dokumentasi lebih baik, administrasi lebih tertata rapi. Adapun dampak yang negatif dapat menambah jam kerja bagi perawat dalam pelaksanaan pelayanan pada pasien.

3. Akreditasi yang baik akan tercapai apabila proses interaksi yang baik antara pihak manajemen Rumah Sakit dan perawat sehingga hambatan yang dirasakan perawat dapat dikendalikan atau diminimalkan.

4. Persepsi perawat berpengaruh langsung terhadap partisipasi dalam pelayanan kesehatan untuk memenuhi tujuan akreditasi Rumah Sakit.

Adzrieman, N., Rahman, A., Mohamad, B., Ashikin, N., \& Rahman, A. (2014, October). Factors Influencing the Quality of e-Services on Hospital Information System (HIS) in Malaysia. Procedia-Social and Behavioral Sciences, 155, 507-512. Diakses dari https:/doi.org/10.1016/i.sbspro.2014.10.331

Ahmadi. (1999). Psikologi Sosial. Jakarta: PT. Rineka Cipta Jakarta.

Ayuningtyas, D. (2015). Perencanaan Strategis Untuk Organisasi Pelayanan Kesehatan (Kedua). Jakarta: Raja Grafindo Persada, Fakultas Kesehatan Masyarakat Universitas Indonesia. Retrieved from http://lib.ui.ac.id/detail?id=20427878

Azwar. (1998). Metode Penelitian. Yogyakarta: Pustaka Pelajar.

Creswell, J. W. (2010). Research Design: Pendekatan Kualitatif, Kuantitatif, dan Mixed. Yogyakarta: PT. Pustaka Pelajar. 
(2015). Penelitian Kualitatif dan Desain Riset. Yogyakarta: PT.

Pustaka Pelajar.

(2017). Research Design: Pendekatan Metode Kualitatif, Kuantitatif, dan Campuran. Yogyakarta: PT. Pustaka Pelajar.

Davis, Keith \& Newstrom. (1989). Human Behavior at Work: Organizational Behavior. New York: McGraw Hill International.

Desiderato, O. (1976). Investigating Behavior: Principle of Psychology. New York: Haper \& Row Publisher.

Irwandy. (2007). Faktor-faktor Yang Berhubungan Dengan Beban Kerja di Unit Rawat Inap RS Jiwa Makassar. Diakses dari https://ejournal-s1.undip.ac.id/index.php/dbr. Volume 4, Nomor 3, Tahun 2015, Hal 1-14 ISSN (Online): 2337-3792

Joint Commission International. (2011). Standar Akreditasi Rumah Sakit. Diakses dari https://docplayer.info/61907072-Standarakreditasi-rumah-sakit-joint-commission-international.html

Kementerian Kesehatan RI. (2017). Peraturan Menteri Kesehatan RI Nomor 34 Tahun 2017 Tentang Akreditasi Rumah Sakit.

Mandawati, M. (2018). Dampak Akreditasi Rumah Sakit:Studi Kualitatif Terhadap Perawat Di RSUD KRT Setjonegoro Wonosobo. Diakses Dari

http://jurnal.unissula.ac.id/index.php/inm/article/download

Manzo, B.F. (2012). Nusing in the Hospital Acrreditation Process: Practice and Implications in the Work Quotidian. Rev. LatinoAm.emfermagem. Vol.20, No.1, hal.151-158.

Moleong. (2014). Metode Penelitian Kualitatif, Edisi Revisi. Bandung: PT Remaja Rosdakarya.

(2017). Metodologi Penelitian Kualitatif. Bandung:


Rosdakarya.

Nasution, S.(1998). Metode Research. Jakarta: PT.Bumi Aksara.

Petriella. Y. (2019). Masih Banyak Rumah Sakit Tak Terakreditasi, Ini Masalahnya. Diakses dari

http://m-bisnis-

com.cdn.ampproject.org/v/s/m.bisnis.com/amp/read/201901 $\underline{07 / 12 / 876080 .}$

PKMK FK UGM. (2019, Mei 21). Dampak Akreditasi Rumah Sakit. Diakses dari

https://manajemenrumahsakit.net/2019/05/21/dampakakreditasi-rumah-sakit/

Potter., Perry. (2013). Kredensial Perawat Antara Tuntutan Akreditasi dan Jaminan Kompetensi. Diakses dari hhtps://joglosemarnews.com

Rahma. (2012). Akreditasi Rumah Sakit, Pengakuan Atas Kualitas Pelayanan. Mutu Pelayanan Kesehatan. Diakses dari http://mutupelayanankesehatan.net/index.php/component/co ntent/article/19-headline/151

Rakmat. (2007). Persepsi Dalam Proses Belajar Mengajar. Jakarta: Rajawali Pers.

Reisi, N., Raeissi, P., dkk. (2018). The Impact of Accreditation on Nurses' Perception of Quality of Care in Iran and Its Barriers Facilitators. Diakses dari https://Int J Health Plann Manage. 2019 Jan;34(1):e230-e240. doi: 10.1002/hpm.2642. Epub 2018 Aug 29

Robbins \& Judge. (2013). Organizational Behavior. New York: Prentice Hall. 
Salusu, J. (2004). Pengambilan Keputusan Strategi untuk Organisasi Publik dan Organisasi Nonprofit. Jakarta: PT. Grasendo Widiasarana Indonesia.

Sarosa. (2012). Penelitian Kualitatif Dasar-dasar. Jakarta Barat: PT. Indeks.

Sobur, A. (2003). Psikologi Umum. Bandung: Pustaka Setia.

Soehartono, I. (2000). Metode Penelitian Sosial. Bandung: PT. Remaja Rosdakarya.

Sopacua, P., Evie. (2006). Akreditasi Sebagai upaya Peningkatan Mutu Pelayanan Rumah Sakit. Diakses dari https://media.neliti.com/media/publications/21171-IDakreditasi-sebagai-upaya-peningkatan-mutu-pelayanan-rumahsakit.pdf

Sugihartono, Dkk (2012). Psikologi Pendidikan. Yogyakarta: UNY Press.

Sugiyono. (2005). Memahami Penelitian Kualitatif. Cetakan keenam. Bandung: Alfabeta.

(2006). Statistika Untuk Penelitian. Cetakan ketujuh. Bandung: Alfabeta.

(2013). Metode Penelitian Kuantitatif, Kualitatif dan R\&D. Bandung: Alfabeta.

(2015). Memahami Penelitian Kualitatif. Bandung: Alfabeta.

(2016). Metode Penelitian Kuantitatif Kualitatif dan Kombinasi (Mixed Methods). Bandung: Alfabeta.

Sukma, S.N.F., Sudiro., Fatmasari, E.Y. (2017, Oktober 4). Analisis Perencanaan Quality Assurance Ditinjau Dari Aspek Input Pelayanan Keperawatan Rawat Inap Pasca Akreditasi Paripurna 
RS Swasta X Kota Semarang. Jurnal Kesehatan Masyarakat (eJournal) Volume 5, Nomor (ISSN: 2356-3346). http://ejournal3.undip.ac.id/index.php/ikm

Surahmat, R., Neherta, M., Nurariati. (2018). Hubungan Karakteristik Perawat terhadap Pelaksanaan Sasaran Keselamatan Pasien Pasca Akreditasi Rumah Sakit " $X$ " di Kota Palembang. Jurnal Ilmiah Universitas Batanghari Jambi Volume 19, Nomor 1, Februari 2019, (Halaman 1-10)

Sutoto. (2017). Standar Nasional Akreditasi Rumah Sakit Edisi 1. Jakarta: Komisi Akreditasi Rumah Sakit (KARS).

Sutoto, A.D., Luwiharsih., Lumenta, N.A., Reksoprojo, M., Martoatmojo, K., Atmatyah, M. (2013). Pedoman Tata Laksana Survei Akreditasi Rumah Sakit. Jakarta: Komisi Akreditasi Rumah Sakit (KARS).

Walgito, B. (2005). Bimbingan dan Konseling (Studi dan Karir). Yogyakarta: CV. Andi Offset.

(2010). Pengantar Psikologi Umum. Yogyakarta: C.V Andi.

Wang, N., Hailey, D., \& Yu, P. (2011). Quality of Nursing Documentation and Approaches to Its Evaluation: a Mixedmethod Systematic Review. Journal of Advanced Nursing, 67(9), 1858-1875

Wibowo. (2013). Manajemen Kinerja. Jakarta: Rajawali Pers.

(2014). Metodologi Penelitian Praktis Bidang Kesehatan. Jakarta: PT Rajagrafindo Persada.

Yuldiz. (2014, April). Perceptions of Nurses On The Impact Of Accreditation On Quality Of Care: A Survey In A Hospital In Turkey. Clinical Governance: An International Journal. Volume 19, Nomor 2, Halaman 69-82. http://journals.ums.ac.id/index.php/article/2014/04/ 
PERSEPSI PERAWAT TENTANG DAMPAK AKREDITASI DI RUMAH SAKIT BUDI MULIA BITUNG
Halaman 192 - 211

Brigita David, dkk 